\title{
An Evaluation of Restitutions Prepared for the Architecture of the Neolithic Site of Göbeklitepe and a Proposition
}

\author{
Göbeklitepe Neolitik Alanı Mimarisi İçin Hazırlanmıș Restitüsyonlar Üzerine \\ Bir Değerlendirme ve Bir Öneri
}

다 Atlıhan Onat KARACALI, (1) Nur URFALIOĞLU

Neolithic studies were mainly about the agriculture. However, the Neolithic was a period where all aspects of human life changed dramatically. Hence, this era must be studied in detail by various disciplines, as well as the architecture. Although small in number, there still are some studies processing the Neolithic architecture. And additionally, there are restitutions drawn for some Neolithic structures. However, the restitutions are heavily based on personal predictions and are open and vulnerable to criticism. Göbeklitepe is a stunning Neolithic findspot from Tukey. Not only by the scale of the structures excavated but also by the facts it offered, this site forced scholars to reconsider what they knew about the early Neolithic. As the much interest increased in time, many studies processed about this site and various restitutions were prepared as well. Once again, these restitutions were personal, and they must be investigated by the facts that scientific studies on the site figured out. And more accurate restitutions for Göbeklitepe must be drawn, matching with same scientific data.

Keywords: Göbeklitepe; neolithic; neolithic architecture; restitution.

Neolitik döneme dair araştırmalar büyük oranda tarım konusu üzerinden yürütülmüştür. Ancak Neolitik, insan yaşantısının tüm yönleriyle değiştiği önemli bir dönemdir. Bu yüzden, bu dönem mimarlık gibi farklı disiplinlerce de derinlemesine incelenmelidir. Görece az da olsalar, döneme dair mimari çalışmalar da yürütülmüştür. Bunlara ek olarak da bazı Neolitik yapılar için restitüsyonlar çizilmiştir. Ancak, restitüsyonlar büyük oranda kişisel tahminlere dayanmaktadır ve bu yönleriyle eleştiriye açıktır. Göbeklitepe, Türkiye'de açığa çıkarılmış çarpıcı bir Neolitik bölgedir. Buluntu yeri; sadece yapıların ölçeği ile değil, sunduğu gerçeklerle de akademik çevreleri erken Neolitik'e dair bildiklerini gözden geçirmek durumunda bırakmıştır. Zaman içinde Göbeklitepe'ye ilgi arttıkça, daha fazla araştırma yürütülmüş ve farklı restitüsyonlar çizilmiştir. Ancak restitüsyonlar yine kişisel niteliktedir ve buluntu yerinde açığa çıkarılan bilimsel veriler doğrultusunda eleştirilmelidir. Ayrıca, aynı verilerle örtüşen daha isabetli Göbeklitepe restitüsyonları da hazırlanmalıdır.

Anahtar sözcükler: Göbeklitepe; neolitik; neolitik mimarisi; restitüsyon. 


\section{Introduction}

The Neolithic findspot of Göbeklitepe is widely acknowledged as a milestone in prehistoric research. Determination of a public structure of this big scale forced scholars to reconsider what they knew about both the social order and the material culture of the Neolithic hunter-gatherers. Göbeklitepe was a public structure of distinct groups to visit. As still no residential structures found, the building complex is believed functionalized for religious rituals, feasts, maybe festivals and as a marketplace for trading goods and knowledge.

Neolithic studies were processed heavily in the agriculture field. However, the Neolithic was a period where all aspects of daily life are changed once and for all. In contemporary researches, overestimation of agricultural studies is criticized. Neolithic, as an important part of the history, must also be evaluated by the other disciplines as anthropology, folklore, art history, and many others, also the architecture as well.

Neolithic architecture researches are much more qualified works than simply production of knowledge about architectural history. First, what is learned from Neolithic structures that shaped directly by simplest human needs can shed light on generating alternatives for contemporary unqualified spaces driven by capitalism and high-technology. More, for the future, the Neolithic architecture researches must be acknowledged important and urgent at dawn of the Mars colonization. Specialists offer that all building material cannot be carried from Earth, and the Martian soil must be functionalized and evaluating adobe as building material reaches as old as the Neolithic age.

Although their small number comparing with the agricultural studies, there are researches about Neolithic architecture in high quality as the ones directed by French archaeologist Olivier Aurenche ${ }^{1}$ and by American archaeologist Kent Flannery. ${ }^{2}$ These studies briefly told that there were two types of buildings in the Neolithic: residences and public structures. They also focused on the plantypes and the materials. Residential structures were transformed from circular to rectangular plantype during the Neolithic. And residences were built heavily with adobe when the public structures were with stone.

There are additional works, come in handy, while studying on Neolithic architecture: the restitutions. Restitution is the expression of unique situations of the historic buildings with architectural representation techniques as drawings, models, computer models, in the light of archives, reports, and photographs if any. Restitutions are expected to be based heavily on personal predictions, where they must be on scientific facts. Therefore, they must be objects to

\footnotetext{
1 Aurenche, 1981, p. 111-112. 2 Flannery, 1972, p. 23-53.
}

valid criticism, comparing with those scientific data. Therefore, the aim of this study is to criticize the existing restitutions prepared for the Neolithic site of Göbeklitepe and finally to propose a new restitution based on the scientific data about the findspot. And in order to understand the Göbeklitepe and the Neolithic architecture, first the concept of the Neolithic period must be studied.

\section{Orientation: The Neolithic}

In social sciences, there is a trend of dividing the history of the planet and civilization into periods. For instance, according to geography and related sciences, current era of the planet is called Quaternary and in the geologic time scale of the International Commission on Stratigraphy, it spans from 2,5 million years ago to the present. Quaternary is divided into two epochs: Pleistocene and Holocene. Pleistocene is up to $10,000 \mathrm{BC}$ and the era which the successive ice ages were seen. Holocene, on the other hand, spans from the end of the Last Glacial Maximum to today. As the temperature raised and the climate turned into available, the first agricultural attempts were shown, at the beginning of the Holocene.

On the other hand, the history and related sciences divide the time, as accepting the spread of writing systems a milestone, as prehistory and the recorded history. Prehistory is divided into epochs by the tool industry as Stone Age, Bronze Age, and Iron Age. This separation was first done by Danish archaeologist Christian Jorgensen Thomsen in the beginnings of 1800 s. $^{3}$ Stone Age is also divided into the Paleolithic, literally "old stone" in Greek, and the Neolithic, the "new stone". This separation, on the other hand, was first done by English archaeologist and anthropologist John Lubbock, in his book Prehistoric Times ${ }^{4}$ (Table 1).

Once, Near East was accepted as the only core that agriculture emerged. Scientists thought that agriculture and other Neolithic developments spread all other continents from this main zone. Contemporary acceptance is however different. Today, multi-central perception of agricultural emergence is more commonly believed. For instance, wheat, barley and goat were domesticated in Near East, boar and rice in Far East, llama and potato in South America, corn in North America, banana and sugar cane in New Guinea. ${ }^{5}$ The answer of why agriculture did not begin in South Africa, Australia, and Alaska is the unavailability of endemic species for domestication. Although the single core view is left, Near East is still the oldest of the centers. So, it has the widest cultural impact area and it is the most systemically researched zone.

The term "Near East" defines the west Asia in broadest terms. Even though the term "Middle East" is used more

\footnotetext{
3 Heizer, 1962, p. 259-266. ${ }^{4}$ Lubbock, 1865, p. $3 .{ }^{5}$ Harari, 2015, p. 90.
} 
Table 1. Time scale of the Neolithic

\begin{tabular}{|c|c|c|c|c|c|}
\hline \multicolumn{2}{|c|}{ Geographic } & \multicolumn{3}{|c|}{ Historic } & Dating \\
\hline \multirow{5}{*}{ Quaternary } & Pleistocene & \multirow{4}{*}{ Pre-history } & \multirow{2}{*}{ Stone } & Paleolithic & \multirow[t]{2}{*}{2,6 Mya - 10,000 BC } \\
\hline & \multirow{4}{*}{ Holocene } & & & Neolithic & \\
\hline & & & \multicolumn{2}{|r|}{ Bronze } & $10,000 B C-3500 B C$ \\
\hline & & & \multicolumn{2}{|r|}{ Iron } & 1000 BC - Spread of writing \\
\hline & & \multicolumn{3}{|c|}{ (Recorded) History } & Writing - Today \\
\hline
\end{tabular}

Table 2. Parts of Near East

\begin{tabular}{l|c|c|c}
\hline \multicolumn{2}{c}{ Near East } \\
\hline \multirow{2}{*}{ Fertile Crescent (Traditional Zone) } & \multirow{2}{*}{ Central Anatolia } \\
\hline \multirow{2}{*}{ Levant } & Mesopotamia & Golden Triangle & \\
\cline { 2 - 3 } & & North Syria Southeast Anatolia & \\
\hline
\end{tabular}

common, Near East is still in use in academic grounds. As used in archaeology, Near East is the geography of Southeast Anatolia and North Syria -the "Golden Triangle", 6 Mesopotamia, West Syria, Lebanon, and Israel -the "Fertile Crescent", ' and Central Anatolia. Important findspots of Near East outside the Anatolia are Jericho in Palestine, Ain Ghazal, Beida, Ba'ja, and Basta in Jordan, Jerf Al-Ahmar, Abu Hureyra, and Ain Mallaha in Syria, Qermez Dere in Iraq (Table 2).

Recent papers mention that the Neolithic is the period that an overall transformation of human life was in progress and must be considered as a giant cultural pack with lots of concrete and abstract elements. According to this opinion, even the name "Neolithic" is exaggerating the tool industry and underestimating the complexity of this cultural pack. In this context, also the ceramic and the architecture must be considered as other civilization milestones, in addition to agriculture. ${ }^{8}$

\section{Agriculture}

The word "agriculture" is defined in encyclopediae and dictionaries as "breeding animals and cultivating plants and fungi, in order to provide food, raw material, biofuel and other productions to sustain and enhance human life". Australian archaeologist Gordon Childe's Agricultural Revolution is the main hypothesis about the beginnings of domestication in academic discussions for long time. ${ }^{9}$ According to this model, in Younger Dryas, the mini ice age in

\footnotetext{
6 Kozlowski and Aurenche, 2001, p. 33-43. 8 Karacalı, 2018, p. 28.

7 Breasted, 1916, p. $101 . \quad 9$ Childe, 1936, p. 15-19.
}

the beginning of the Holocene, rain-loaded low pressure left Near East and moved to Europe. In dried Fertile Crescent, both the animals and humans gathered around water sources decreasing in number. This way of food sharing between species evolved into agriculture. Another critical hypothesis about the beginning of agriculture is American archaeologist and anthropologist John Robert Braidwood's Hilly Flanks concept, proposed in $1948 .{ }^{10}$ The geography of this idea is Taurus and Zagros Mountains, on the north of Fertile Crescent. Not only the geography, but also the construct of the hypothesis is opposite of the Agricultural Revolution. According to the Hilly Flanks, shown area is rich in the number of water sources and the wild ancestors of today's domesticated animals. And people transformed their lifestyle into agriculture not by drought, but by observing the advantages. There are much more theories about the beginning of agriculture, and all models can be collected into push-or-pull system. That means agriculture started by reasons either challenging or beneficial. Another contemporary common opinion is that, agriculture was not a "revolution" as sudden impact, but a process experienced slowly in long term.

\section{Ceramic}

Both the existence and absence of ceramic is overrated in Neolithic literature. Ceramic, in these terms, mean the production of utensils by firing formed adobe. Scholars handle this ceramic issue not as one of the inventions but as the symbol of agricultural production. Once, ceramic

\footnotetext{
${ }^{10}$ Redman, 1978, p. 95-97.
} 
Table 3. Parts of the Neolithic

\begin{tabular}{|c|c|c|c|}
\hline \multirow{3}{*}{ Neolithic } & \multirow{2}{*}{$\begin{array}{c}\text { Pre-Pottery } \\
\text { Neolithic }\end{array}$} & Pre-Pottery Neolithic A (PPNA) & $10,000 B C-8500 B C$ \\
\hline & & Pre-Pottery Neolithic B (PPNB) & $8500 B C-7000 B C$ \\
\hline & \multicolumn{2}{|c|}{ Pottery Neolithic } & $7000 B C-3500 B C$ \\
\hline
\end{tabular}

was perceived as a characteristic of Neolithic age. However, English archaeologist Kathleen Kenyon discovered Neolithic layers without ceramic in her Jericho excavations in 1950s. Therefore, the Near Eastern Neolithic is divided into two epochs: Pre-Pottery Neolithic (PPN) and Pottery Neolithic (PN) ${ }^{11}$ Also, the Pre-Pottery Neolithic is divided into PPNA and PPNB periods. In PPNA, hunting-gathering was still the main system as in previous Paleolithic age, the most primitive agricultural attempts as selective gathering was experiencing, and religious activities as burials spread. In PPNB, increasing number of species were domesticated and agricultural economy was in progress. As an outcome of increasing population, new social and religious activities were produced and as an outcome of ensuring the food supply, new specializations as craftsmanship and merchantry were introduced. Finally, in Pottery Neolithic, food production is totally settled in human life as the main economic system (Table 3 ).

\section{Architecture}

In all periods of the history, the architecture is the clear indicator of lifestyle, culture, economy, and the level of technology. In Paleolithic age, people first took caves and tree hollows as shelters, later they designed temporary open-air hunter-gatherer camps. During the Neolithic, architecture was in progress parallel with the increasing sedentarism through the agricultural practices. Once the sedentary life was accepted as emerged with agriculture, however now scholars believe that sedentarism began before but spread with domestication processes. On the other hand, as for the agriculture also for the sedentarism, traditional Fertile Crescent opinion is left and a multicentral perception is accepted on contrary. Even in the late discovered Central Anatolian findspots, architectural levels from earliest phases of Neolithic were found.

There are distinctive signs of Neolithic Near Eastern villages in terms of architecture, comparing with the other Neolithic zones of the world. While other Neolithic zones were quite stable, Near Eastern villages were accelerated in technologic developments and finally invented metallurgy, and they were going to be transformed into city-states and empires in the end. Second, there was enormous settlements in Near East. For instance, Catalhoyuk from

\footnotetext{
${ }^{11}$ Kenyon, 1981, p. 167-271.
}

Central Anatolia was not a simple agricultural village but a gigantic proto-city. Third, even in the earliest phases of the Neolithic era, different functional zones were defined in Near Eastern villages. For each of these zones, there were two types of structures in those villages: residences and public structures. ${ }^{12}$ According to studies mentioned above, residential structures were circular in the PPNA, however in PPNB storage and partially the production transferred indoors, and the buildings became rectangular in plantype. And during Pottery Neolithic, residences became functionally parted and sometimes second storeys were designed.

According to researches, as the plantypes, a generalization of both building materials and techniques can be made. In the beginning of the Neolithic, residences were in quite vernacular identity. Like bushes, brunches, animal hide and bones, what can be found in the surrounding were functionalized as building material. In brief time, the soil also became available and more permanent structures were built to adapt more sedentary hunter-gatherer camps. Soil was first used in wattle-anddaub technique, and then in superimposing and pisé techniques. Finally, sun-dried adobe brick was invented. Also, the scholars think that the increasing excellence in use of soil as building material gave way to invention of the ceramic. In Pottery Neolithic, as stated above, there could be functionalized roofs or second floors. In multistoreys structures, daily life was transferred into second floor and the basement volume was used as stables or granaries. This design transcended 7000 years, and still can be seen in Middle Eastern village architecture. Not just the functions of storeys, but even also the measurements of adobe bricks remained. The last feature about Neolithic residences is their cult objects great in number. Labelled symbolic or cosmologic in literature, these objects were wall paintings, reliefs, figurines and artistically treated skulls. Neolithic residences were not only volumes designed for daily life, but also places with somehow religious identity.

Second type of structure in Neolithic was the public structures. They were constructed with special material and technique, greater than the houses, and rich in ornaments. The furniture, like seats surrounding volumes

\footnotetext{
${ }^{12}$ Karacali, 2018, p. 41.
} 


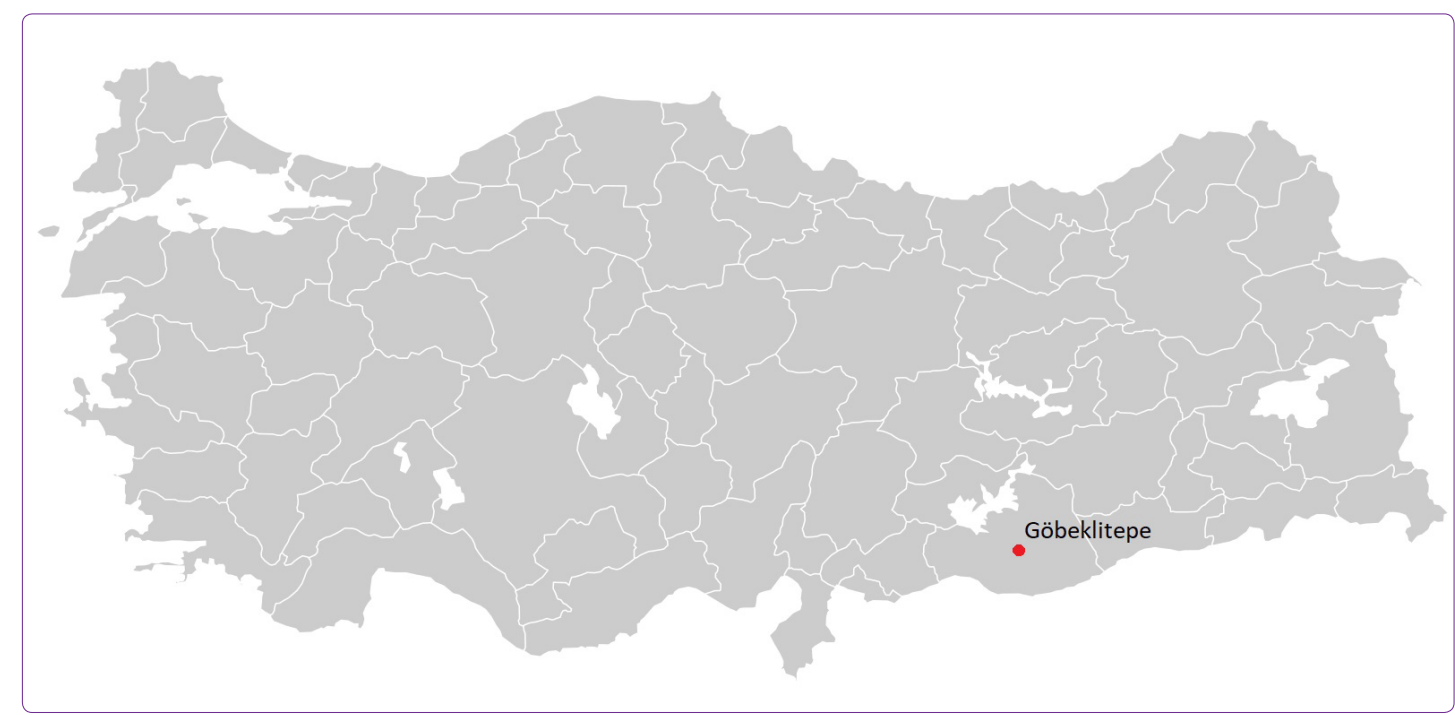

Figure 1. Göbeklitepe on Map of Turkey (drawn by author upon the figure on https://commons.wikimedia.org/ wiki/File:Turkey_provinces_blank_gray.svg [Accessed 12 September 2018]).

all around, display the design logic for communal function. In literature, they are often called "temple", "cult building", "special structure", or "monumental buildings". There are opinions like calling them "public structures"13 in order to prevent impatient results. There is no detailed knowledge about the beginnings of the public structures. Recent studies claim that they were defined even in semisedentary camps before agriculture. The samples from Southeast Anatolia the north of Fertile Crescent, including Göbeklitepe, have common features like circular plan, terrazzo floor, and T-shaped pillars. There must be a design language followed as T-pillars were used as a design tool in those public structures. Two bigger ones placed in the center of circle, and many smaller ones, typically twelve, were placed around. All pillars were decorated with reliefs of wild animals and abstract symbols. Waterproof terrazzo floors mean that the base could be filled with a liquid like water or blood. And as mentioned the building material for public structures was mainly stone where it was adobe in residences. The materials have languages, and architects use them as a design and evaluation mechanism. Stone is more solid and powerful in this term.

\section{Focus: The Neolithic Site of Göbeklitepe}

Anatolia, as an inner-zone of the Near East, is roughly the peninsula in between the Black Sea and the Mediterranean. In contemporary use, Anatolia is the Asian territory of Republic of Turkey. According to TAY Project (The Archaeological Settlements of Turkey), including both surveys and excavations, there are more than 450 Neolithic sites in Turkey. Although this much number of findspots spread all regions of the country, there are concentrations

\footnotetext{
${ }^{13}$ Stordeur et al., 2000, p. 29-44.
}

on Southeast Anatolia and Central Anatolia. It is the reason why Anatolian Neolithic is researched on these two cores in related literature. Southeast Anatolian findspots show similarities with the Fertile Crescent settlements where Central Anatolia findspots show an overall unique way of progression, especially in architecture.

Central Anatolia was long believed unavailable for $\mathrm{Ne}$ olithic settlements. Researches in recent period, as James Mellaart's survey in 1950, and the works of David French and lan Todd, showed that there are giant and long-established findspots in the area, on contrary. Important findspots are Aşıklıhöyük and Çatalhöyük in front and Musular, Can Hasan, Erbaba, and Hacılar. Establishment of Southeast Anatolia, on the other hand, as a Neolithic zone was within The Joint Istanbul - Chicago Universities Prehistoric Research in 1960s. Until now, many findspots in the area were excavated. Where the other important findspots are Çayönü, Hallan Çemi and Nevali Çori, the most systemically researched one is the Göbeklitepe.

Göbeklitepe (37 $1323 \mathrm{~N}, 385520 \mathrm{E}$ ) is close to the modern Turkish city of Şanlıurfa (Fig. 1). Findspot is dated as old as $10,000 \mathrm{BC}^{14}$ and about $8000 \mathrm{BC}$ the structures were filled with dust and the site was abandoned. As there is a lack of residential structures and the closest water source is at $4 \mathrm{~km}$ distance, the findspot is not accepted as a settlement. Closest settlement contemporary with Göbeklitepe was Nevali Çori, which is at $48 \mathrm{~km}$ distance. ${ }^{15}$ As it was not a regular settlement, it is difficult to evaluate the economy of Göbeklitepe. However, as stone tools relating distinct cultures were present, ${ }^{16}$ the structures are accepted as built

\footnotetext{
${ }^{14} \mathrm{https}$ ://whc.unesco.org/en/ ${ }^{16} \mathrm{https} / / /$ tepetelegrams. wordpress. list/1572

${ }^{15}$ Collins, 2016, p. 44.
} 
Table 4. Göbeklitepe Layers

\begin{tabular}{c|c|c|c}
\hline Layer & Dating & Neolithic Phase & Building Type \\
\hline Layer III & $10,000 \mathrm{BC}-9000 \mathrm{BC}$ & PPNA & Circular Public Spaces \\
\hline Layer II & $9000 \mathrm{BC}-8000 \mathrm{BC}$ & PPNB & Rectangular Public Spaces \\
\hline Layer I & $8000 \mathrm{BC}-$ Today & - & - \\
\hline
\end{tabular}

in co-operation of multiple societies. ${ }^{17}$ And as the animal bones found in plenty, those constructers were thought to be fed by food brought from distant hunts. Göbeklitepe is accepted to have an impact area of $200 \mathrm{~km}$ radius.

\section{Göbeklitepe: Excavations}

Göbeklitepe was first found as an archaeological site in 1963, within the Joint Prehistoric Research mentioned. However, it was labelled as a graveyard at that time and the project was not progressed. The rediscovery of Göbeklitepe was achieved by archeologist Klaus Schmidt from German Archaeological Institute (DAI) in 1994. This time the accurate function of the site was appreciated. Once studied in another Southern Anatolian Neolithic site, the Nevali Çori, Schmidt realized the findings previously labelled gravestones were in fact architectural pillars. In 2003, a geomagnetic survey was processed to figure out the total number of structures under the mound. Schmidt directed the excavations until his pass in 2014. In 2017, a protective roof was constructed above the site. And in 2018, Göbeklitepe made it to the UNESCO World Heritage List.

During the Schmidt's excavations, three layers were determined. Oldest one with the widest known circular structures, the Layer III was dated to 10,000 BC and PPNA period. Above this, the Layer II with rectangular structures were dated to $9000 \mathrm{BC}$ and PPNB period. Shallowest one on top, the Layer I consists of the earth gathered since the abandonment of the site until today ${ }^{18}$ (Table 4). Studies widely processed at Layer III which the huge amount of available data comes from. As seen, through the Neolithic civilization achievements, Göbeklitepe constructed and used totally in Pre-Pottery Neolithic when the huntergatherer economy was the main system.

\section{Göbeklitepe: Public Structures}

At broadest sense, Göbeklitepe consists of several circular structures with different radii in tangent arrangement. For structural features, the smallest constituent of the site are the massive limestone pillars (Fig. 2). Form of these pillars is of a long prismatic body and a wider prismatic head

\footnotetext{
${ }^{17}$ https://tepetelegrams.wordpress. of-hunter-gatherers-at-early-neolithcom/2016/09/22/building- big- ic-gobekli-tepe/

incentives- for- cooperative-action- ${ }^{18}$ Dietrich et al, 2013, p. 36-40.
}

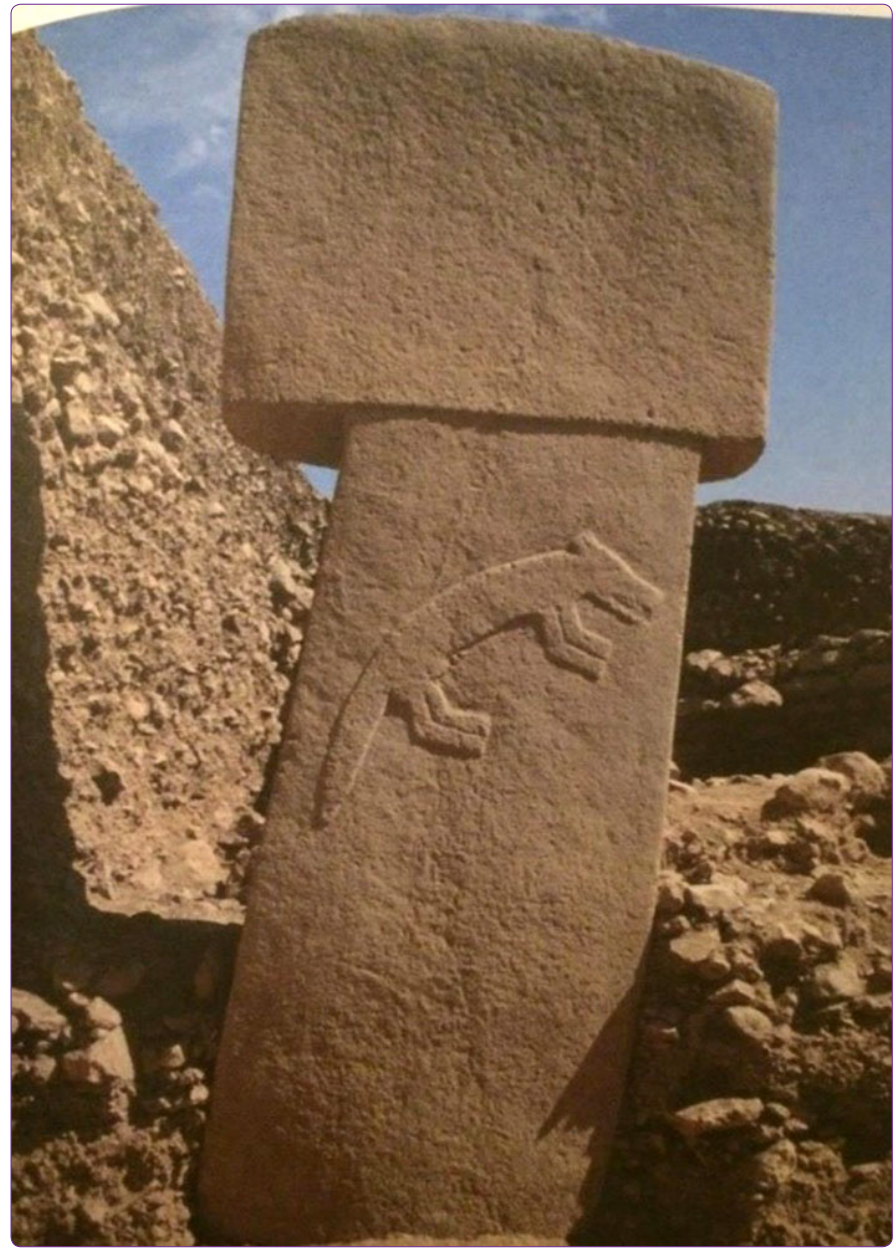

Figure 2. A Göbeklitepe Pillar (Schmidt, 2007, p. 181).

on top. These T-shaped pillars can be as tall as 5,5m and as heavy as 16 tons. ${ }^{19}$ Around the mound, limestone quarries were found. And in one of them, an unfinished pillar of $7 \mathrm{~m}$ in length was discovered. Near all pillars have rich reliefs of either animals like bull, fox, crane, boar, spider, and snake or abstract symbols. Creating a pantheon of wild animals seems conceivable for hunter-gatherers. According to Schmidt, these pillars were anthropomorphic descriptions. ${ }^{20}$ Clearly observable arm and hand reliefs on some pillars undoubtedly support this view.

\footnotetext{
${ }^{19}$ Mann, 2001, p. $41 . \quad{ }^{20}$ Schmidt, 2007, p. 116.
} 

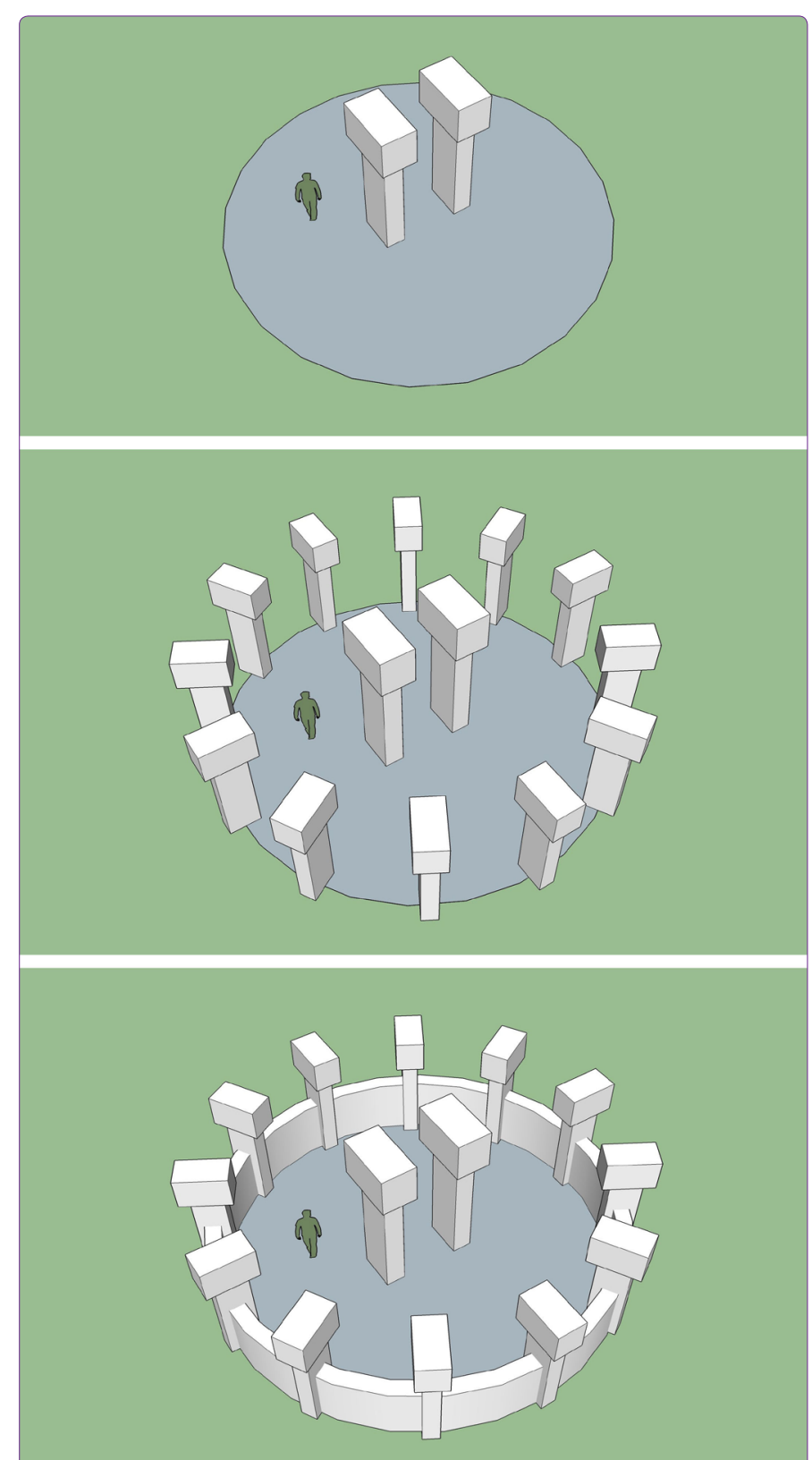

Figure 3. Design Language of Göbeklitepe Structures (Karacalı, 2018, p. 66-67).

By the pillars, circular structures with available diameters over $30 \mathrm{~m}$ were assembled. As mentioned above, the architectural design language offers to place two bigger pillars in the center and to install numerous small pillars orbiting them around. The distances between the surrounding pillars were filled with stone masonry and each structure were enclosed (Fig. 3). In some structures, there is a seat-like raised platform at the bottom of surrounding wall. These were thought to be designed for audience watching the action happening in the center. Floors of the structures were of waterproof terrazzo material. As there is no evidence of roofs, the site is accepted as an open-air complex.

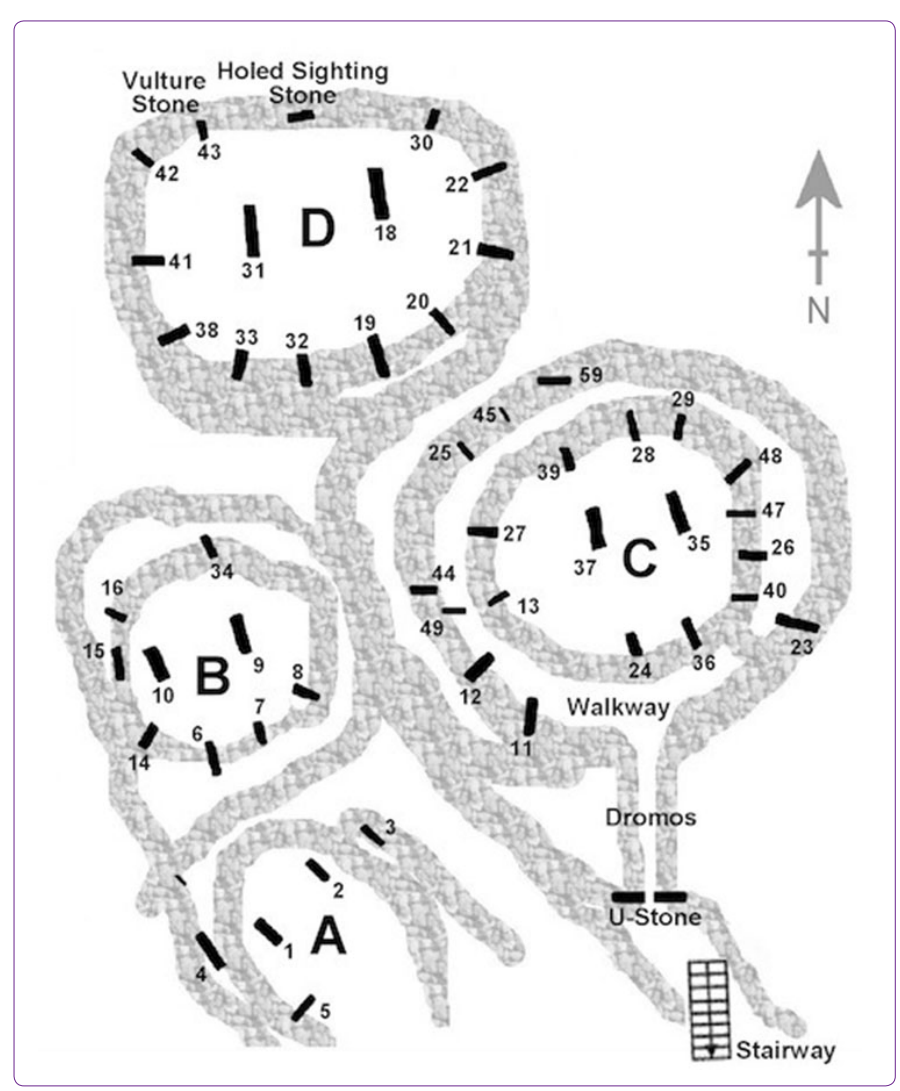

Figure 4. Göbeklitepe Excavation Plan (http://www.andrewcollins. com/page/articles/G\%F6bekli_Sirius.htm).

Until today seven of these circular structures were excavated and according to the geomagnetic survey in 2003, there are more than twenty within the mound. ${ }^{21}$ The assemblage of this big structure complex by the known $\mathrm{Ne}$ olithic cultures is quite surprising. When the weight of pillars and the distance of quarries thought, there must be a need for great workforce. These views support the idea of separate groups gathering for the construction project.

Four of the structures opened were in the main excavation area and were labelled with letters in order (Fig. 4). They were also named with animals according to reliefs they exhibit. "Enclosure A" or the "Snake Building" ("Schlangenpfeilergebäude" in German, "pfeiler" for pillar and "gebäude" for structure) was found in 1996. Plantype of this building is close to rectangle but it is considered within circular structures. "Enclosure B" or "Fox Building" ("Fuchspfeilergebäude" in German) was excavated in 1998 and its diameter is about $10 \mathrm{~m}$. "Enclosure C" or "Boar Structure" ("Wildschweinpfeilergebäude" in German) consists of a number of telescopic circular walls and the diameter is over $30 \mathrm{~m}$ at largest. These structures comes front not only with the volume but also with the rich reliefs. Differently from others, Enclosure $C$ is supported with a long entrance corridor and a definite door. "Enclosure $D$ " or

\footnotetext{
${ }^{21}$ Schmidt, 2003, p. 5
} 
"Crane Structure" ("Kranichpfeilergebäude" in German) is in oval plantype and longer diameter is over $20 \mathrm{~m}$. This is the most protected one of the four. Other circular structures opened were placed out of the main excavation area.

From the functional perspective, what is absent at Göbeklitepe becomes as important as what is present. The mound is partially excavated but still nothing found proving domestic usage of structures. Absence of both hearths and graves point that those structures were not residences. According to Schmidt, those were temples and he believed, motivation behind the gathering of separate groups was their belief. Similar structures with T-shaped pillars were found at the settlements within the impact area of Göbeklitepe. However, they were less in number and surrounded with residences. Schmidt thought that those were the temples of each settlement and the Göbeklitepe was something like a temple complex and a pilgrimage center on top of the hierarchy. ${ }^{22}$ Göbeklitepe must be a magnet not just at the construction but also during the usage and here must be political meetings, idea and product trades, and even the feasts, as well as the cult activities. Managing this much crowd needs a social hierarchy, and this is an opposing view against the traditional acceptance of egalitarian social pattern of Pre-Pottery Neolithic.

Another interesting point is the abandonment of the site. Before the Pottery Neolithic era began, the structures of Göbeklitepe were filled with earth and the site was left. Abandonment of structures either with filling with earth or with burning is a common activity in Neolithic. Some scholars think one structure was filled and another began to be constructed in Göbeklitepe, where some views offer that they were in use simultaneously. According to Schmidt, the dating relationship in between the four structures in main excavation area was left undefined. He also predicted that they might be constructed at the same time. ${ }^{23}$ Radiocarbon tests ${ }^{24,25,26}$ processed at the field indicate opposing views. Some tests were applied to the embankment earth and were unhelpful in determining construction dates. At least, there is a single healthy result from the surrounding wall of Enclosure D and it offers $9984 \pm 42$ BC as the construction date. When the knowledge both from Neolithic architecture and Göbeklitepe layers unite with this date, there can be a prediction for dating of each of four structures respectively. According to this view ${ }^{27}$ Enclosure D must be the oldest, Enclosure $C$ must be next and symbolize the rise of Neolithic culture, Enclosure B must be next and symbolize the collapse of Neolithic culture through the end of the Pre-Pottery Neolithic, and Enclosure A must be the newest as it is the smallest one proving the knowl-

\footnotetext{
${ }^{22}$ Schmidt, 2007, p. 280-281.

${ }^{23}$ Schmidt, 2007, p. 257.

${ }^{24}$ Dietrich, 2011, p. $12-25$.
}

edge of late PPNA and more rectangular in plantype symbolizing the transformation through the Pottery Neolithic.

\section{Target: Göbeklitepe Restitutions}

As mentioned above, the existing restitutions prepared for Göbeklitepe is going to be criticized in this chapter. Restitution in Figure 5 was prepared by Italian artist Fernando Baptista for National Geographic USA June 2011 issue. Enclosure $C$ is shown finished and Enclosure $D$ is shown under construction. Baptista's work seems close to scientific facts by form and material. However, it can be criticized due to building order. Enclosure D must be the oldest in between the central structures opened.

Restitution in Figure 6 was prepared by Turkish artist Erhan Balıkçı for TUBITAK Bilim ve Teknik (Science and Technique) July 2014 issue. According to direction arrow pictured, those structures must be Enclosure $C$ and Enclosure D. Telescopic walls for Enclosure $C$ can be appreciated. However, the entrance corridor and the door for Enclosure

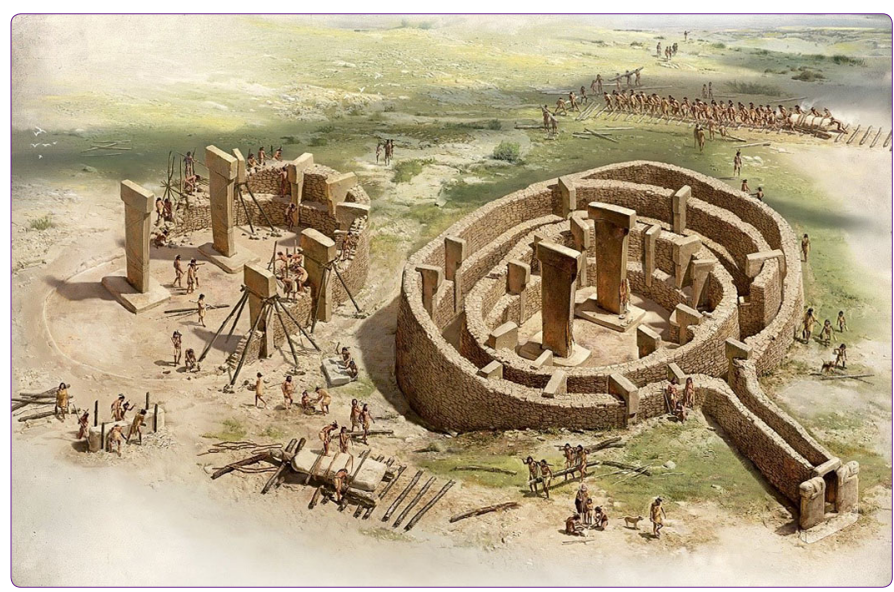

Figure 5. Fernando Baptista's Göbeklitepe Restitution (Mann, 2001, p. 44-45).

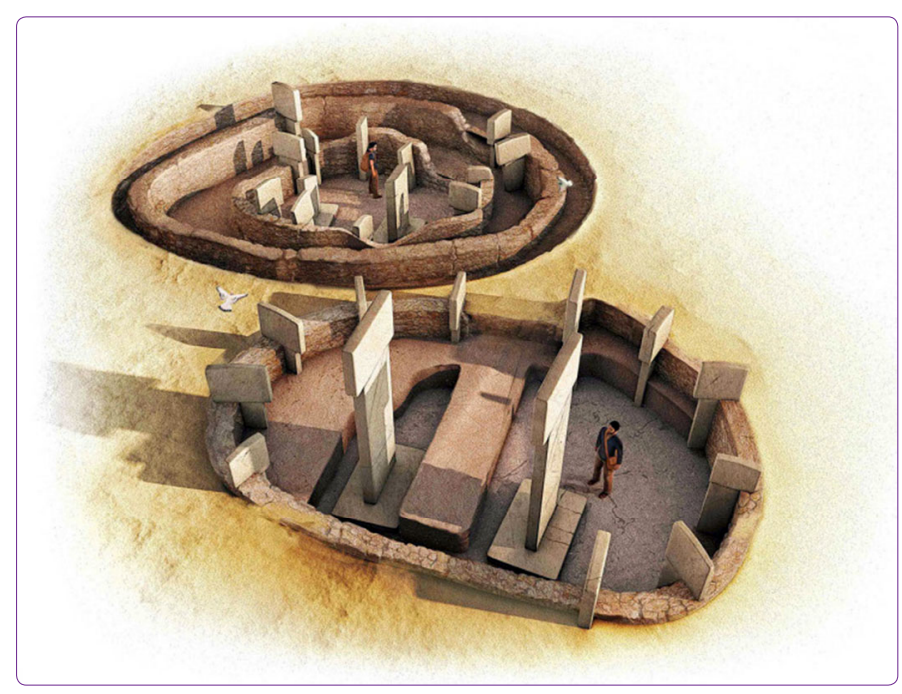

Figure 6. Balıkçı's Göbeklitepe Restitution (http://newspagedesigner. org/photo/g-beklitepe). 
C were not depicted. More, there is no evidence offering the floor level of structures below the surrounding surface.

Restitution in Figure 7 was prepared by German Archaeological Institute which processed the excavations. The structures depicted must be Enclosures B, C and D. Drawing can be appreciated for depicting unexcavated buildings with hollow circles and presenting the entrance corridor for Enclosure C. However, walls of the structured were drawn thicker than those were in excavation plans.

Restitution in Figure 8 was prepared by Turkish painter Abdurrahman Birden. His work seems heavily personal. Structures are not placed in the exact positions. More, displaying both circular and rectangular structures in the same level obviously conflicts with the scientific facts.

Restitution in Figure 9 is from Turkish director Ahmet Turgut Yazman's documentary movie titled "Göbeklitepe: The World's First Temple". This work must be appreciated for depicting the materials close to the facts. On the other hand, presenting the structure alone without the adjacent ones and defining an entrance space must be criticized.

Restitution in Figure 10 is from Italian astrophysicist Giulio Magli's works about the relationship of positions of Göbeklitepe structures and Sirius stars. This study seems designed not for depicting the material and form of the structures but for showing its orientation directed to the star mentioned. Therefore, the structure seems quite $a b-$ stract and the circular pillars seem extremely tall.

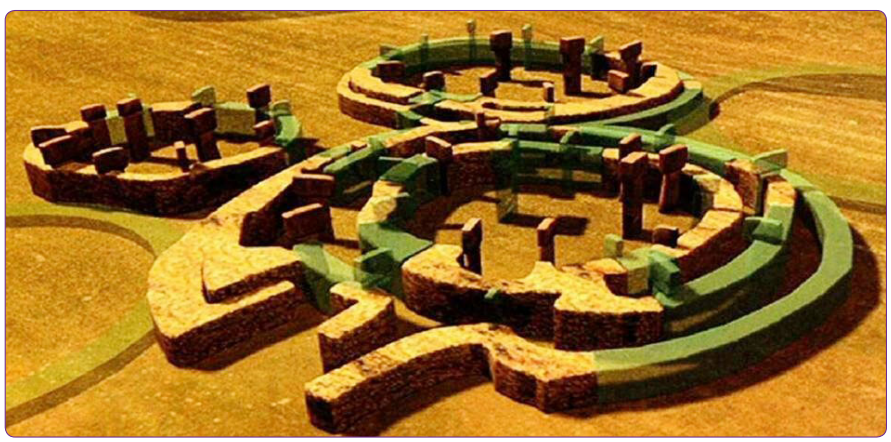

Figure 7. German Archaeological Institute's Göbeklitepe Restitution (http://www.historiasztuki.com.pl/strony/001-01-PREHISTORIA.html).

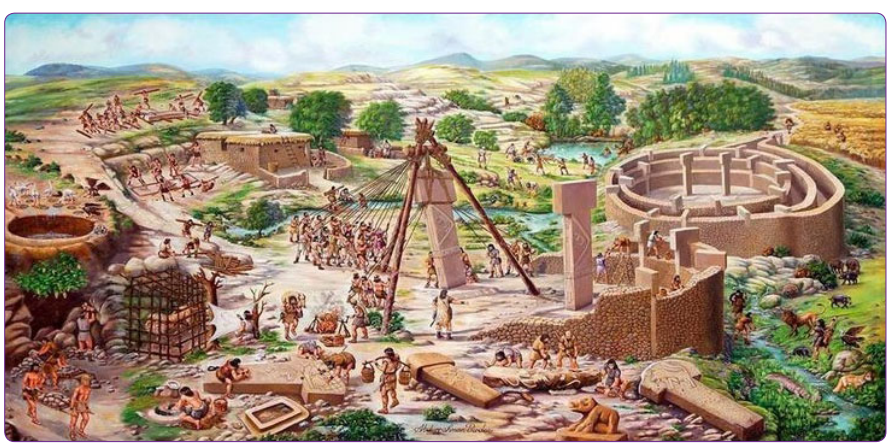

Figure 8. Birden's Göbeklitepe Restitution (https://twitter.com/sanliurfaicin/status/482344574573346816).

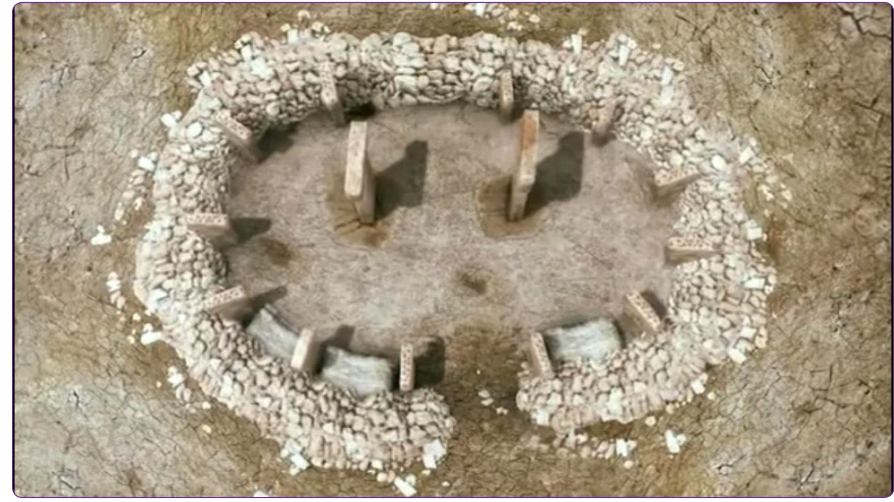

Figure 9. Göbeklitepe Restitution in Yazman's Movie (https://www. youtube.com/watch?v=kIGOCGUSTI4).

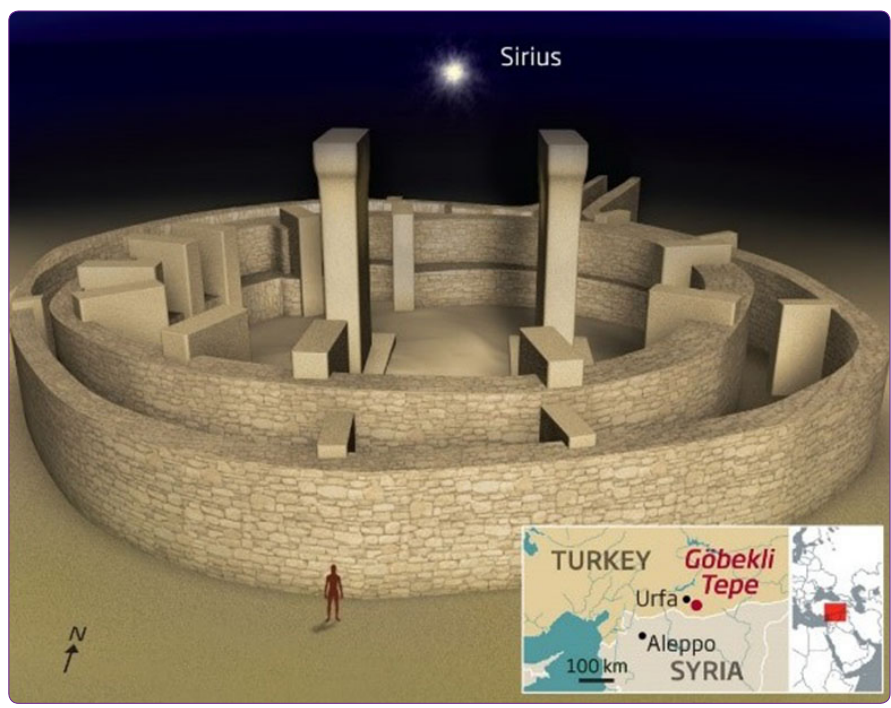

Figure 10. Göbeklitepe Restitution in Magli's Studies (https://www. newscientist.com/article/mg21929303-400-worlds-oldest-templebuilt-to-worship-the-dog-star/).

\section{Result: A Propositional Göbeklitepe Restitution}

As mentioned above, a new propositional Göbeklitepe restitution is going to be offered in this chapter. In this study, the original drawings from excavation reports were used to create bigger central and smaller surrounding pillars, and the "U Stone" used as the door for Enclosure C. As this restitution is an architectural work, pillars were abstracted, and reliefs were not depicted. More, in order to figure out the exact position, dimension and orientation of the pillars, the excavation plan was used (Figs. 11 and 12) Other structures were later drawn with same order explained above. Once again, the excavation plan helped with the form of the stone walls surrounding the structures. There must be more structures simultaneously in use, but in order to stick scientific facts, only the excavated four were depicted. Finally, the materials, shades and surrounding terrain were added. After finished, this restitution seems the closest one ever to the scientific facts comparing with the restitutions criticized above (Fig. 13). 

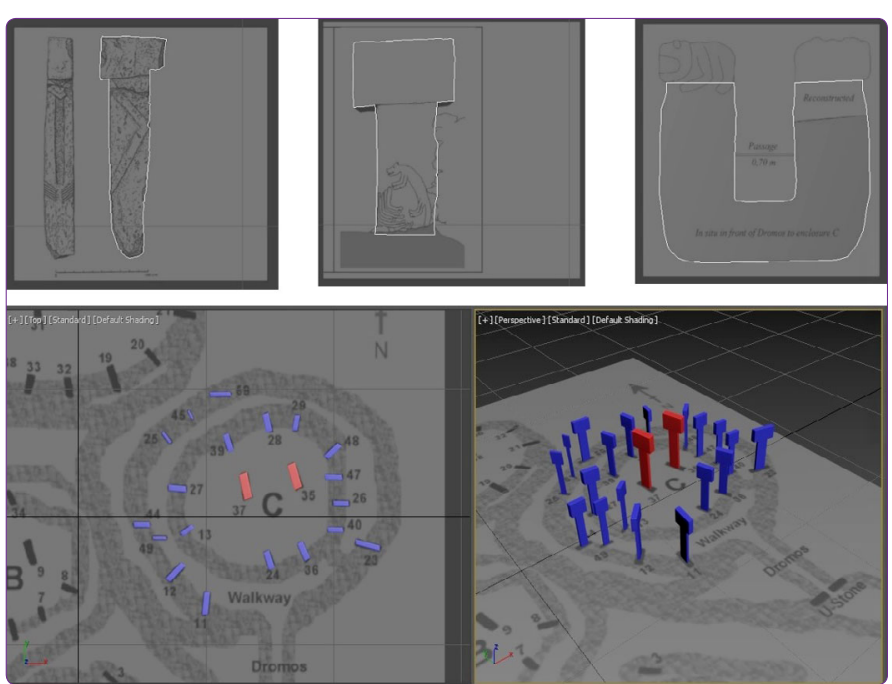

Figure 11. Preparation of Propositional Göbeklitepe Restitution (drawn by author Karacalı of this study on 3DS Max 2016).
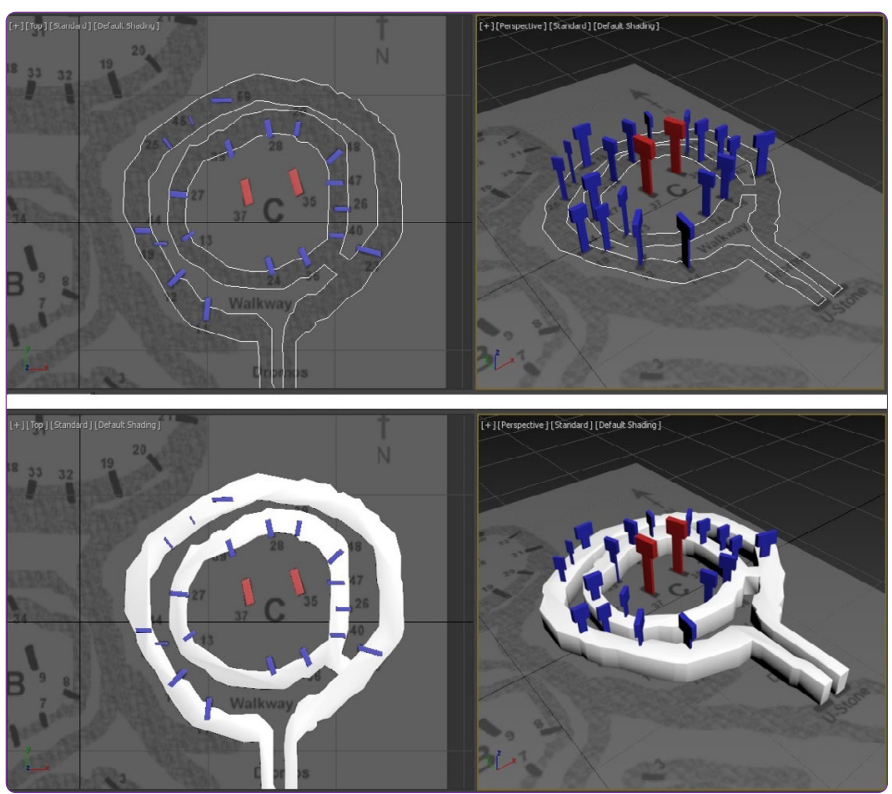

Figure 12. Preparation of Propositional Göbeklitepe Restitution (drawn by author Karacalı of this study on 3DS Max 2016).

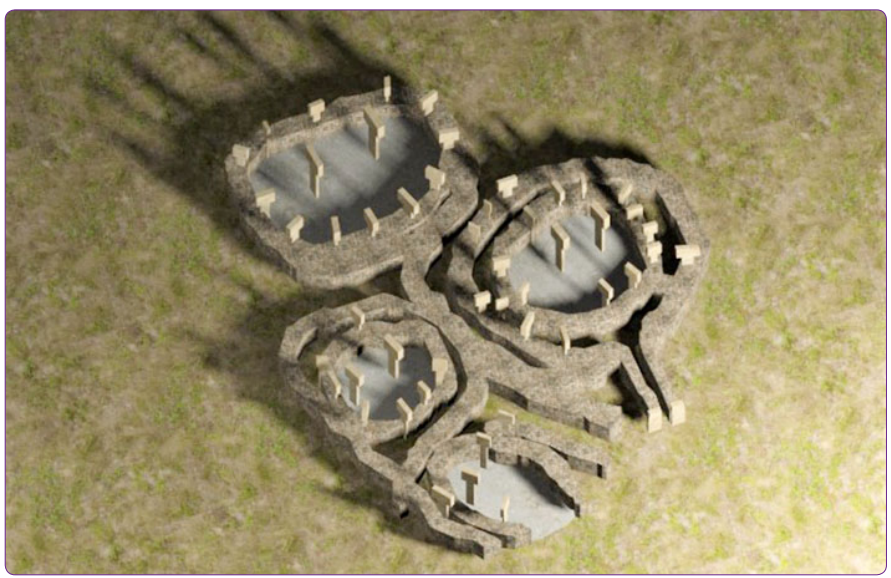

Figure 13. Propositional Göbeklitepe Restitution (drawn by author Karacalı of this study on 3DS Max 2016).

\section{References}

Aurenche, O. (1981) “La Maison orientale. L'Architecture du Proche-Orient ancien des origines au milieu du IVe millénaire", Paléorient, Vol.8, No.2, p. 111-112.

Breasted, J. H. (1916) Ancient Times: A History of the Early World, Boston, Ginn and company.

Childe, G. (1936) Man Makes Himself, London, Watts\&Co.

Collins, A. (2016) Göbeklitepe ve Tanrıların Doğuşu, İstanbul, Alfa.

O. Dietrich, Köksal-Schmidt, C., Notroff, J., and Schmidt, K. (2013) "Establishing a Radiocarbon Sequence for Göbekli Tepe. State of Research and New Data", Neo-Lithics No.1/13, p. 36-41.

Dietrich, O. (2011) "Radiocarbon dating the first temples of mankind. Comments on 14C-Dates from Göbekli Tepe", Zeitschrift für Orient-Archäologie, No.4, p. 12-25.

Flannery, K. V. (1972) "The Origins of the Village as a Settlement Type in Mesoamerica and the Near East", Ed P. J. Ucko, R. Tringham and G.W. Dimbleby, Man, Settlement and Urbanism, Duckworth, p. 23-53.

Harari, Y. N. (2015) Hayvanlardan Tanrılara Sapiens İnsan Türünün Kısa Bir Tarihi, İstanbul, Kolektif.

Heizer, R. (1962) “The background of Thomsen's Three-age System", Technology and Culture, Vol.3, No.3, p. 259-266.

Karacalı, A. O. (2018) Neolitik Yakındoğu ve Göbeklitepe Mimarisi, Ankara: Gece Kitaplığı.

Kenyon, K. M. (1981) Excavations at Jericho: Volume Three. The Architecture and Statigraphy of the Tell, London, British School of Archaeology in Jerusalem.

Kozlowski, S. K. and Aurenche, O. (2001) "Le Croissant fertile et le 'Triangle d'or'", Etudes M'esopotamiennes: receuil de textes offert a Jean-Louis Huot, Editions Recherche sur les Civilisations, p. 33-43.

Kromer, B. and Schmidt, K. (1998) "Two Radiocarbon Dates from Göbekli Tepe, South Eastern Turkey", Neo-Lithics, No.3, p. 8-9.

Lubbock, J. (1865) Pre-historic Times: As Illustrated by Ancient Remains, and the Manners and Customs Of Modern Savages, London, Williams and Norgate.

Mann, C. C., (2011) "The Birth of Religion: The World's First Temple"', National Geographic, Vol.219, No.6 (June 2011), p. 39-59.

Redman, C. E (1978). Rise of Civilization: From Early Hunters to Urban Society in the Ancient Near East. San Francisco, Freeman.

Schmidt, K. (2003) "The 2003 Campaign at Göbekli Tepe (Southeastern Turkey)" NeoLithics, No.2/03, p. 2-8.

Schmidt, K. (2007) Taş Çağı Avcılarını Gizemli Kutsal Alanı Göbeklitepe En Eski Tapınağı Yapanlar, İstanbul, Arkeoloji ve Sanat Yayınları.

Stordeur, D., Brenet, M., Der Aprahamain, G., Roux, J. C. (2000) "Les batiments communautaires de Jerf el Ahmar et Mureybet, horizon PPNA (Syrie)”, Paléorient, Vol.26, No.1, p. 29-44.

\section{Internet References}

http://newspagedesigner.org/photo/g-beklitepe [Accessed 12 September 2018]

http://www.andrewcollins.com/page/articles/G\%F6bekli_Sirius. htm [Accessed 9 August 2016]

http://www.historiasztuki.com.pl/strony/001-01-PREHISTORIA. 
html [Accessed 12 September 2018]

https://commons.wikimedia.org/wiki/File:Turkey_provinces_ blank_gray.svg [Accessed 12 September 2018]

https://tepetelegrams. wordpress.com/2016/05/18/who-builtgobekli-tepe/ [Accessed 9 August 2016]

https://tepetelegrams.wordpress.com/2016/09/22/buildingbig-incentives-for-cooperative-action-of-hunter-gatherers-at-early-neolithic-gobekli-tepe/ [Accessed 31 October 2016] https://twitter.com/sanliurfaicin/status/482344574573346816 [Accessed 12 September 2018]

https://whc.unesco.org/en/list/1572 [Accessed 13 August 2018] https://www.newscientist.com/article/mg21929303-400worlds-oldest-temple-built-to-worship-the-dog-star/ [ACcessed 12 September 2018]

https://www.youtube.com/watch?v=kIGOCGUSTI4 [Accessed 12 September 2018] 